https://helda.helsinki.fi

The effect of salt reduction on taste pleasantness in cooked pÿ Bologna-type sausages

\title{
Ruusunen, Marita
}

Blackwell Publishing

1999

Journal of sensory studies. 1999. 14(2): 263-270.

http://hdl.handle.net/1975/712

Downloaded from Helda, University of Helsinki institutional repository.

This is an electronic reprint of the original article.

This reprint may differ from the original in pagination and typographic detail.

Please cite the original version. 
THE EFFECT OF SALT REDUCTION ON TASTE PLEASANTNESS IN COOKED ‘BOLOGNA-TYPE’ SAUSAGES

M. RUUSUNEN, M. SÄRKKÄ-TIRKKONEN and E. PUOLANNE

Department of Food Technology, University of Helsinki, POB 27 (Viikki E), FIN00014, Helsinki, Finland

Correspondence: Marita Ruusunen, Dept. of Food Technology, University of Helsinki, POB 27 (Viikki E), FIN-00014, Helsinki, Finland email: marita.ruusunen@helsinki.fi 


\section{ABSTRACT}

This study's objective was to study how much the salt $(\mathrm{NaCl})$ content of cooked sausage can be reduced without violating the perceived taste pleasantness. 34 assessors evaluated seven cooked sausages made with added salt concentrations of $1.05 ; 1.20 ; 1.35 ; 1.50 ; 1.65 ; 1.80$ and $1.95 \%$. A relative-to-standard scale was used for rating the saltiness and taste pleasantness. The saltiness and pleasantness intensity of different salt concentrations was rated against a reference sausage, which contained 1.5\% added salt. A reference sample was also hidden among the samples. The assessors were able to rank sausages based on the saltiness into the right order. Based on taste pleasantness, there was no significant difference between the sausages made with $1.35 ; 1.50 ; 1.65 ; 1.80$ or $1.95 \%$ added salt $(\mathrm{p}>0.05)$. Several differences were, however, detected among the saltiness levels. The results of this study suggest that it might be possible to reduce the salt content of cooked sausage to $1.35 \%$ added salt.

\section{INTRODUCTION}


There is strong evidence that sodium elevates blood pressure in most individuals and in the population as a whole thus causing an increased risk of cardiovascular diseases (Law et al. 1991a, 1991b, Frost et al. 1991). There are also opposite opinions about the exact nature of the sodium-hypertension link. High salt intake does not necessarily induce essential hypertension in all individuals (McCarron 1998). $\mathrm{NaCl}$ is the biggest source of sodium. Sodium constitutes $39.3 \%$ of $\mathrm{NaCl}$. It has been established that on a population basis the habitual consumption of more than $6 \mathrm{~g} / \mathrm{day}$ of salt is associated with an age-increase in blood pressure (Anon 1988). The average daily intake of salt (added sodium chloride) in Finland is $10.5 \mathrm{~g}$ for men and $7.2 \mathrm{~g}$ for women (Anon 1998). Meat products made up 20\% of the salt intake in 1994.

Salt $(\mathrm{NaCl})$ is added to foods as a flavoring or flavor enhancing agent, a preservative, and an ingredient responsible for the desired textural properties e.g. in meat products. The saltiness of $\mathrm{NaCl}$ is mainly produced by $\mathrm{Na}^{+}$cations. The preferred level of salt in food is dependent on the amount of salt consumed. Many studies have shown that sodium levels can be reduced by 30 to $50 \%$ without affecting taste and consumer acceptability. The reduction must happen slowly over several months. (Bertino et al. 1982). The water-binding capacity of cooked sausages increases almost linearly when the salt content is raised to about to $2.0-2.5 \% \mathrm{NaCl}$ (Puolanne and Ruusunen 1980). Salt also enhances the microbiological shelf life of refrigerated meat products.

The salt content of Finnish cooked sausages usually ranges from 1.6 to 2.2\%, and of cooked hams from 1.9 to $2.7 \%$ (Ruusunen et al. 1995). These are equivalent to 629 $865 \mathrm{mg} \mathrm{Na} / 100 \mathrm{~g}$ in cooked sausages and to 747 - $1061 \mathrm{mg} \mathrm{Na} / 100 \mathrm{~g}$ in cooked hams, 
respectively. During the past 25 years the salt content in meat products has been reduced, e.g the salt content of sausages was on average $2.36 \%$ in 1973 , and $1.73 \%$ in 1995 (Karanko and Puolanne 1996). Despite this reduction in sausage salt content no reaction has been shown in consumer consumption yet. The salt content of Finnish meat products will continue to be reduced. The aim of this study was to determine how much the salt content can be reduced without violating taste pleasantness.

\section{MATERIALS}

The recipe for the sausages are presented in Table 1 . The added salt concentrations were $1.05 ; 1.20 ; 1.35 ; 1.50 ; 1.65 ; 1.80$ and $1.95 \%$. Sausage batters were stuffed into a casing (80 mm diameter) and cooked at $76^{\circ} \mathrm{C}$ to achieve an endpoint product temperature of $72^{\circ} \mathrm{C}$. After cooking, the sausages were placed in a $3{ }^{\circ} \mathrm{C}$ cooler overnight. 
TABLE 1.

The sausage recipes.

\begin{tabular}{ll}
\hline \hline & Amount $(\mathrm{kg})$ \\
\hline Beef & 2.63 \\
Pork & 2.46 \\
Pork skin & 0.50 \\
Potato flour & 0.60 \\
Salt (NaCl) & $0.105-0.195$ \\
Phosphate & 0.025 \\
NaNO 2 (10 \%-solution) & 0.012 \\
Ascorbic acid & 0.006 \\
Spices & 0.021 \\
Water & 3.56 \\
Total & $9.919-10.009$ \\
\hline
\end{tabular}

METHODS

$\underline{\text { Salt and sodium content }}$

The $\mathrm{NaCl}$ concentration of sausages was determined by analyzing the chloride-ion content. Sodium content was analyzed with an Na-selective electrode (Kivikari 
1996). The Na-selective electrode method was a modification of Averill's (1983) and Kühne’s (1988) method.

\section{$\underline{\text { Sensory evaluation }}$}

Thirty-four assessors evaluated the sausages. They all were specialists in sensory analysis. The sausages were prepared once, but two replicates of the sensory evaluations were conducted. A relative-to-standard scale was used for rating the saltiness and pleasantness of the sausages (Figure 1) (Tunaley et al., 1987). At each session, either the saltiness intensity or the pleasantness intensity of cold sausages of seven different salt concentrations was rated against a reference sausage, which contained $1.5 \%$ added salt. A reference sample was also hidden among the samples. The assessors did not know that the hidden reference sample was among the samples. The order of sample presentation was randomized within assessors. The reference sausage was tasted immediately before each of the other sausages. The assessors rinsed their mouths with water between each sample. Saltiness or pleasantness intensity ratings were recorded by marking the appropriate point on a $100 \mathrm{~mm}$ continuous line scale (Figure 1). The assessors were told that the mid-point of the scale (marked 'standard') represented the saltiness or pleasantness intensity of the 1.5\% added $\mathrm{NaCl}$ sausage open reference sample. 


\begin{tabular}{lcc}
$\begin{array}{l}\text { Much less } \\
\text { salty }\end{array}$ & Standard & $\begin{array}{l}\text { Much more } \\
\text { salty }\end{array}$ \\
\hline-50 & 0 & +50 \\
$\begin{array}{l}\text { Much less } \\
\text { pleasant }\end{array}$ & Standard & $\begin{array}{l}\text { Much more } \\
\text { pleasant }\end{array}$ \\
1 & 1 & $\perp$ \\
\hline-50 & 0 & +50
\end{tabular}

FIG 1. RELATIVE-TO-STANDARD SCALE USED FOR RATING SALTINESS AND PLEASANTNESS

\section{$\underline{\text { Statistical analysis }}$}

The data was analyzed statistically using the SAS program (SAS Institute Inc., 1989). All saltiness and pleasantness values were corrected according to Powers et al. (1977) by multiplying the saltiness and pleasantness values of each assessor with w (weight coefficient). The weight coefficient (w) was calculated by the following formula: $\mathrm{w}=10 /\left(10+\left|\mathrm{x}_{\mathrm{k}}-\mathrm{x}_{\mathrm{u}}\right|\right)$, where $\mathrm{x}_{\mathrm{k}}=0$ is the score the assessor should give to the reference sample (standard sample) and $\mathrm{x}_{\mathrm{u}}$ is the score she/he gave to the hidden reference sample. If both $\mathrm{x}_{\mathrm{k}}$ and $\mathrm{x}_{\mathrm{u}}$ were zero, the weight $(\mathrm{w})$ attached to the judgment was taken as one. If the assessor makes a misjudgment the weight was less than one.

The differences in saltiness and pleasantness between the sausages with different amounts of added salts were studied using a two-way analysis of variance. The two factors were assessors and added $\mathrm{NaCl}(\%)$. A t-test with a significance level of $\mathrm{p}=0.05$ was used to locate the differences. 


\section{RESULTS AND DISCUSSION}

TABLE 2.

Analyzed salt and sodium content of the sausages.

\begin{tabular}{llll}
\hline \hline Added $\mathrm{NaCl}(\%)$ & $\begin{array}{l}\text { Analyzed } \mathrm{NaCl}(\%) \\
\text { (based on chloride }\end{array}$ & $\begin{array}{l}\text { Analyzed sodium } \\
(\mathrm{mg} / 100 \mathrm{~g})\end{array}$ & $\begin{array}{l}\text { Analyzed } \mathrm{NaCl}(\%) \\
\text { (based on sodium }\end{array}$ \\
& analysis) & & 1.30 \\
\hline 1.05 & 1.14 & 511 & 1.42 \\
1.20 & 1.24 & 558 & 1.52 \\
1.35 & 1.38 & 597 & 1.70 \\
1.50 & 1.54 & 668 & 1.85 \\
1.65 & 1.68 & 727 & 1.94 \\
1.80 & 1.80 & 762 & 2.18 \\
1.95 & 1.95 & 857 &
\end{tabular}

The analyzed salt content of the reference sausage based on chloride analysis was 1.54\% and based on sodium analysis $1.70 \%$ and the sodium content was $668 \mathrm{mg}$ $\mathrm{Na} / 100 \mathrm{~g}$ (Table 2). In this study, the salt content of reference sausage was chosen to be little lower than the salt content in Finnish sausages on average, which is $1.73 \%$ based on chloride analysis (Karanko and Puolanne 1996). The assessors could rank the sausages in the correct order of saltiness (Figure 2). The hidden reference sausage 
was, however, evaluated differently than the open reference sausage based on saltiness and pleasantness (Figures 2 and 3). The difference can be considered to be a normal variation in sensory evaluations and it does not add any notable errors to the results. Because the assessors did not know that they were also assessing the reference sample, they seldom evaluated it as salty or pleasant. It has to be considered also that the overall pleasantness of reference sausage was not known, and the scale is based on a comparison with the open reference sausage, only.

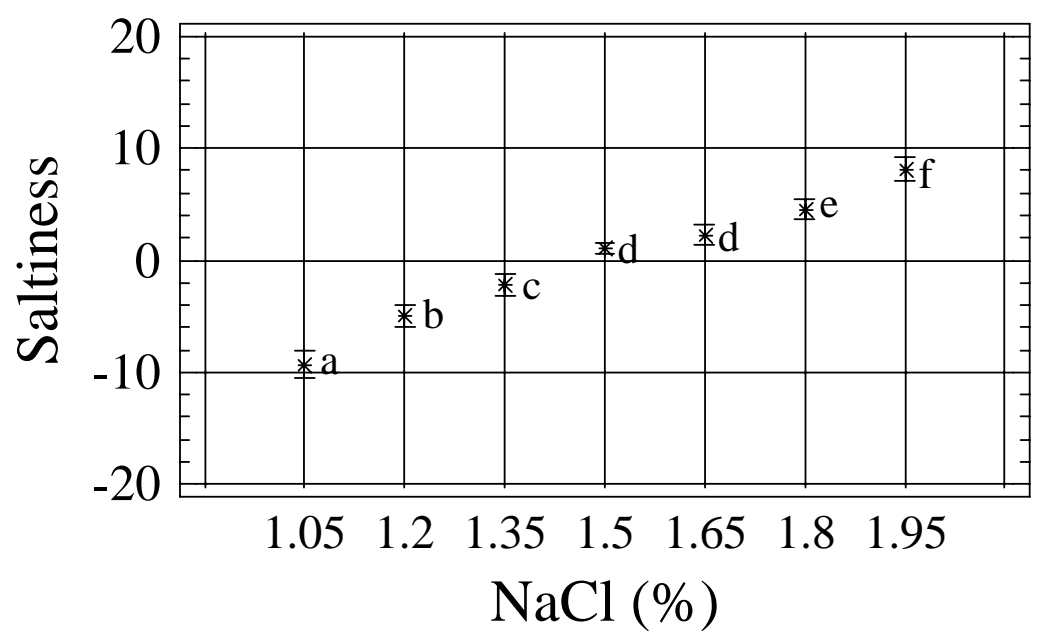

FIGURE 2.

The saltiness of the sausages.

Means and standard errors. ${ }^{\text {abcdef }}$ Saltiness means with no common superscript differ significantly $(\mathrm{p}<0.05)$

The sausage with 1.05\% added salt was less pleasant than the hidden reference sample $(\mathrm{p}<0.05)$ (Figure 3). Based on pleasantness, there was no difference between the sausages made with $1.5,1.35$ or $1.20 \%$ added salt ( $>0.05$ ). Above $1.80 \%$ added salt, however, the pleasantness of the sausages was reduced (Figure 3). 


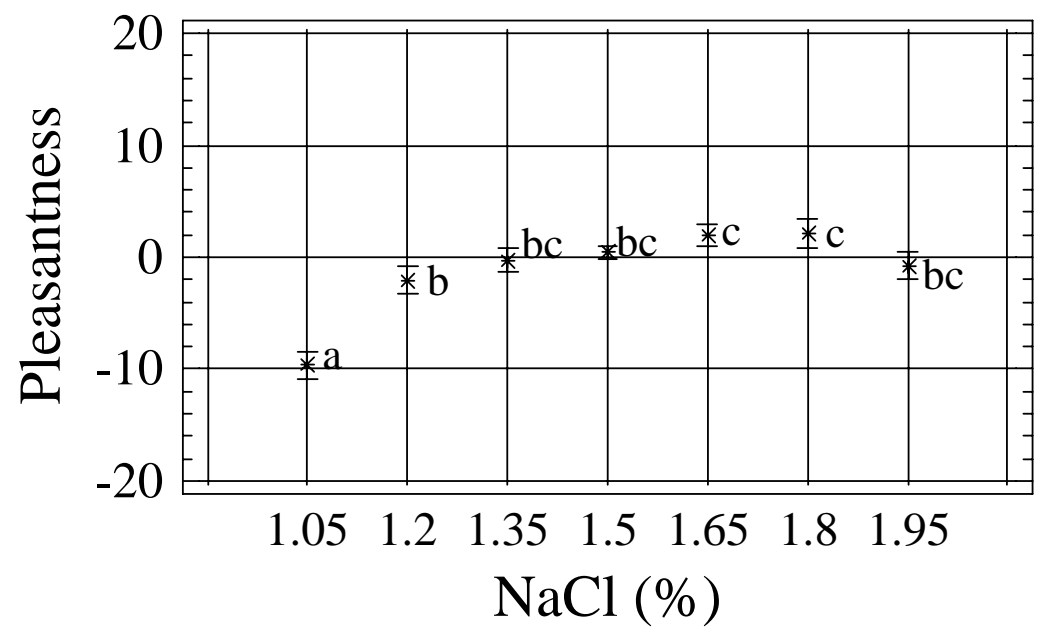

FIGURE 3.

The pleasantness of the sausages.

Means and standard errors. ${ }^{\text {abc }}$ Pleasantness means with with no common superscript differ significantly $(\mathrm{p}<0.05)$

In Finland it is allowed to label a sausage casing 'low-salt content' if the salt content is less than $1.3 \%$ salt based on a chloride analysis. If the salt content is over $1.8 \%$, the sausage casing must be labeled 'high-salt content'. The industry is interested in reducing the salt content of the sausages to $1.2 \%$ or lower, because they would like to offer the consumers sausages with lower sodium content than they do nowadays. Based on this study, the lowest salt content in relation to pleasantness is $1.20-1.35 \%$ added salt when a sausage with $1.5 \%$ added salt is used as a pleasantness reference sausage. The most pleasant sausages were, however, the sausages with 1.65 and $1.80 \%$ added salt. There were no significant differences in pleasantness between the sausages made with $1.35 ; 1.50 ; 1.65 ; 1.80$ or $1.95 \%$ added salt ( $>>0.05$ ) (Figure 3 ). 
The salt content of meat products in Finland is already on average lower than in many other countries, but cooked sausage consumption is quite high; in 1997, 22.5 $\mathrm{kg} / \mathrm{person} /$ year. Up to now it has been possible to reduce the salt content of sausages, and the consumers have accepted the products. It seems, however, that the assessors are not yet willing to consume sausages with only $1.2 \%$ added salt. When reducing the salt content of the food, tastelessness is anticipated to be the biggest problem related to consumer acceptance. Therefore, it is now difficult to predict whether consumers are ready to accept further reductions in salt content in cooked sausages. Further research is needed on how to strengthen the taste and pleasantness of low salt sausages.

\section{CONCLUSIONS}

The results of this study suggest that it might be possible to reduce the salt content of cooked sausage to $1.35 \%$ added salt. 


\section{ACKNOWLEDGMENTS}

This research was funded by the Social and Health Ministry. We thank all the assessors who took part in sensory analyses. 


\section{REFERENCES}

ANON 1988. Intersalt Cooperative Research Group. Intersalt an international study of electrolyte excertion and blood pressure. Results for 24 hour urinary sodium and potassium excertion. British Medical J. 297: 319-328.

ANON 1998. The 1997 Dietary Survey of Finnish adults. Reports from National Public Health Institute B8/1998.

AVERILL, W.F. 1983. Ion-selective electrode system measures sodium content of foods. Food Technol. June: 44-52, 56

BERTINO, M., BEAUCHAMP, G.K. and ENGELMAN, K. 1982. Long-term reduction in dietary sodium alters the taste of salt. Am. J. Clin. Nutr. 36:1134-1144. FROST, C., LAW, M. and WALD, N. 1991. By how much does dietary salt reduction lower blood pressure. II . Analysis of observational data within populations. British Medical J. 302:815-818.

KARANKO, E. and PUOLANNE, E. 1996. Makkaroiden kemiallinen koostumus vuosina 1973-95. (Chemical composition of Finnish sausages in 1973 - 95). Lihapäivät 1996. Hy/elintarviketeknologian laitoksen julkaisuja no. 536. KIVIKARI, R. 1996. Natriumin analysointi lihavalmisteista Na-selektiivisellä elektrodilla. (Analysis of sodium in meat products using an Na-selective electrode). Lihapäivät 1996. University of Helsinki, Department of Meat Technology, reports from meat technology Nr. 536, ss 64-66.

KÜHNE, D. 1988. Analysis of common salt and sodium in meat products. Fleischwirtsch. 68:1007-1010. 
LAW, N., FROST, C. and WALD, N. 1991a. By how much does dietary salt reduction lower blood pressure. I - Analysis of observational data among populations. British Medical J. 302: 811-815.

LAW, N., FROST, C. and WALD, N. 1991b. By how much does dietary salt reduction lower blood pressure. III - Analysis of data from trials of salt reduction.. British Medical J. 302: 819-824.

McCARRON, D. A. 1998. Diet and blood pressure - the paradigm shift. Science 281:933-934.

POWERS, J.J., GODWIN, D.R. and BARGMANN, R.E. 1977. Relations between sensory and objective measurements for quality evaluation of green beans. ACS Symposium series 51:51-70.

PUOLANNE, E. and RUUSUNEN, M. 1980. Kochsalz und Phosphat in ihrer Wirkung auf das Wasserbindungsvermögen von Brühwurst. Fleischwirtsch. 60:13591362.

RUUSUNEN, M., MANTERE-ALHONEN, S., SALOVAARA, H. and PUOLANNE, E. 1995. Suola elintarvikkeiden rakenteeseen vaikuttavana tekijänä. (The Effect of salt on the texture of food stuffs). Kehittyvä Elintarvike (5):19-24.

SAS Institute Inc. 1989: SAS/STAT User’s Guide. Version 6 Fourth edition, Vol. 2. Gary, NC. 846 p.

TUNALEY, A., THOMSON, D.M.H. and McEWAN, J.A. 1987. Determination of equi-sweet concentrations of nine sweeteners using a relative rating technique. Intern. J. of Food Sci. and Technol. 22:627-635. 